\title{
Solvent Extraction of Light Rare Earths from Acidic Medium by Di-(2-ethylhexyl) Phosphoric Acid in Kerosene
}

\author{
(Pengekstrakan Pelarut Nadir Bumi dari Medium Berasid dengan Asid \\ Di-(2-ethylhexyl) Phosphoric di dalam Kerosin)
}

Khaironie Mohamed Takip*, Masturah Markom \& Meor Yusoff Meor Sulaiman

\section{ABSTRACT}

\begin{abstract}
An organophosphorus reactant, D2EHPA, in kerosene has been employed as an extractant for solvent extraction of a mixture of light rare earths (La(III), Nd(III) and Ce(IV)) from acidic nitrate and sulphuric medium. Effect of various concentrations of acidic solutions and extractant on the extraction of rare earths was investigated. The experiments were carried out under various concentrations of aqueous phase of acidic solutions (0.1-0.5 M) and organic phase of D2EHPA (0.1-1 M) at organic-to-aqueous (O/A) phase ratio of 1. The effect of temperature on extraction was also studied by varying temperature range from 278 to $318 \mathrm{~K}$. Extraction equilibrium time was investigated to determine the optimum time for extracting the studied rare earths. It was found that the extraction of $99.4 \%, 99.7 \%$ and almost 100\% for La(III), $\mathrm{Nd}(\mathrm{III})$ and $\mathrm{Ce}(\mathrm{IV})$, respectively, was achieved from $0.1 \mathrm{MHNO}$ feed solution with $1 \mathrm{MD} 2 \mathrm{EHPA}$ at room temperature. The process showed that the selective extraction was in order of $L a(I I I)<N d(I I I)<C e(I V)$. The loaded organic was stripped with various concentration of several acidic solutions ( $\mathrm{HCl}, \mathrm{HNO} 3$ and $\mathrm{H}_{2} \mathrm{SO}_{4}$ ) at $\mathrm{O} / \mathrm{A}$ phase ratio of 1 . It was found that the recoveries of $\mathrm{La}(\mathrm{III})$ and $\mathrm{Nd}(\mathrm{III})$ to the strip liquor were relatively moderate (45.2-67.7\%), whereas losses of Ce(IV) were very low $(<1.5 \%)$.
\end{abstract}

Keywords: D2EHPA; rare earth; solvent extraction; stripping

ABSTRAK

Bahan tindak balas organofosforus, D2EHPA dalam kerosin telah digunakan sebagai bahan pengekstrak bagi pengekstrakan pelarut campuran unsur nadir bumi ringan (La(III), Nd(III) and Ce(IV)) daripada bahantara berasid nitrik dan sulfurik. Kesan kepekatan larutan berasid dan bahan pengekstrak kepada pengekstrakan nadir bumi ini telah dikaji. Eskperimen dijalankan dengan beberapa kepekatan fasa berair larutan berasid (0.1-0.5M) dan fasa organik D2EHPA (0.1-1M) pada nisbah fasa organik kepada fasa berair (O/A) ialah 1. Kesan suhu pengekstrakan juga dikaji dengan mempelbagaikan julat suhu antara $278 \mathrm{~K}$ hingga $318 \mathrm{~K}$. Masa keseimbangan pengekstrakan dikaji untuk menentukan masa optimum bagi mengekstrak unsur nadir bumi. Didapati masing-masing menunjukkan pengekstrakan 99.4\%, 99.7\% dan hampir 100\% untuk La(III), Nd(III) dan Ce(IV) diperolehi dari larutan suapan 0.1M HNO dengan 1 M D2EHPA pada suhu bilik. Proses menunjukkan aturan selektif pengekstrakan unsur ialah $\mathrm{La}(\mathrm{III})<N d(I I I)<C e(I V)$. Organik yang penuh telah dilucutkan dengan larutan berasid ( $\mathrm{HCl}, \mathrm{HNO}_{3}$ and $\mathrm{H}_{2} \mathrm{SO}_{4}$ ) yang berbeza kepekatan pada nisbah fasa O/A bersamaan 1. Didapati perolehan La(III) dan Nd(III) pada likor lucut berpatutan (45.2-67.7\%) manakala Ce(IV) sangat rendah $(<1.5 \%)$.

Kata kunci: D2EHPA; nadir bumi; pengekstrakan pelarut; perlucutan

\section{INTRODUCTION}

Applications of rare earth elements (REE) are becoming crucial of late in many high technology industries due to their unique physicochemical properties. Rapidly increasing range of applications is depending on their magnetic, chemical, electrical, catalytic and optical properties (Gupta \& Krishnamurty 2005). Some applications may need a mixture of REE such as europium, terbium, and yttrium for rare earth phosphors, while neodymium and praseodymium for magnets but other application may require single rare earth element such as cerium for catalytic converter and lanthanum, the most reactive REE, for special optical glass.
The main minerals from rare earth mines such as bastnesite ( $\mathrm{La}, \mathrm{Ce}) \mathrm{FCO}_{3}$, monazite $(\mathrm{Ce}, \mathrm{La}, \mathrm{Y}, \mathrm{Th}) \mathrm{PO}_{4}$ and xenotime $\left(\mathrm{YPO}_{4}\right)($ Clark 1984), are among the significantly marketable compounds.

As the commercial demands for REE and their compounds are considerably high, separation and recovery of individual REE from minerals are essential. Though numerous separation techniques to separate and recover REE namely membrane separation, chemical absorption, and distillation have been extensively studied, solvent extraction has always been the popular technique at all time. It has been accepted as the most practical system for separation the REE based on the bulky volume of liquid handling need 
(Brown \& Sherrington 1979; Sherrington 1983; Peppard et al. 1953, 1957a, 1957b). The processes of separating and purification of REE using solvent extraction have been employed more than 60 years ago where the first solvent extraction plant was installed to treat hydrometallurgical solutions at the mine site for the recovery of uranium in late 1940s (Douglas 2005). The separation of individual REE from each other is challenging due to the resemblance of their physical and chemical properties. Indeed, the extraction and separation ability are highly dependable on the chemical structure of the extractant having effective ligands. Three major classes of extractant, namely, anion exchangers (or basic extractants), cation exchangers (or acidic extractants) and solvation extractants (or neutral extractants) have been collectively utilized for solvent extraction and separation of REE. However, the family of acidic extractants obtained as by-products of phosphorics (D2EHPA), phosphonic (EHEHPA, HEHEHP, P507, PC88A) and phosphinic acids (Cyanex 272, P229) seems to be more effective in extracting REE from aqueous solutions (Abdeltawab et al. 2002; Li et al. 2006). D2EHPA (di-2-ethylhexyl phosphoric acid) is among the first and the most widely investigated extractant in separation of REE (Antico et al. 1996; Basualto et al. 2013; Huang et al. 2008; Rabie 2007; Sato 1989; Thakur 2000).

In this study, D2EHPA (di-2-ethylhexyl phosphoric acid) in kerosene was used as the extractant of choice for extraction of lanthanum (III), neodymium (III) and cerium (IV) from acidic solutions. The purpose of this study is to investigate the effect of acidic solution $\left(\mathrm{H}_{2} \mathrm{SO}_{4}\right.$ and $\left.\mathrm{HNO}_{3}\right)$ together with D2EHPA concentrations, temperature and equilibration time on the solvent extraction of light rare earth elements (LREE). The stripping experiments were carried out to investigate the preferable stripping agent for further stripping study and the feasibilities of LRE separation are discussed.

\section{EXPERIMENTAL DESIGNS}

Several laboratory tests were carried out to as to meet the objectives of study.

\section{MATERIALS}

The rare-earth oxides ( $>99.99 \%)$ of $\mathrm{La}(\mathrm{III}), \mathrm{Nd}(\mathrm{III})$ and $\mathrm{Ce}(\mathrm{IV})$ as well as the commercial extractant D2EHPA (95\%) were all purchased from Sigma-Aldrich Chemical Company. Distilled kerosene and acid solutions including $\mathrm{H}_{2} \mathrm{SO}_{4}$ (95\%), $\mathrm{HNO}_{3}(65 \%)$ and $\mathrm{HCl}(37 \%)$ were supplied by R\&M Chemical Company. All chemicals were used as analytical reagent grade.

An inductively coupled plasma mass spectrometry (ICPMS) was used for determining rare earth concentration from extraction and stripping experiments.

\section{METHODS}

The stock solution of LREE was prepared by dissolving some amount of corresponding rare earth oxides in small volume of concentrated hydrochloric acid and desiccated to almost dryness to remove excess acid. It was then diluted to $1 \mathrm{~L}$ with double distilled water. Solution samples of various concentrations of $\mathrm{H}_{2} \mathrm{SO}_{4}$ and $\mathrm{HNO}_{3}$ were prepared by mixing fixed volumes of stock solution with varying volumes of concentrated $\mathrm{H}_{2} \mathrm{SO}_{4}$ and $\mathrm{HNO}_{3}$ and double distilled water. The organic phase solution was prepared by dissolving specific amount of D2EHPA in distilled kerosene and diluted to the required concentration. Both acidic solutions and D2EHPA were diluted using the relation of molarity $(\mathrm{M})$ and volume (V) as following:

$$
M_{1} V_{1}=M_{2} V_{2}
$$

where " 1 " represent the concentrated conditions and "2" represents the desired diluted conditions.

Extraction Solvent extraction experiments were carried out at room temperature $(298 \mathrm{~K})$ by contacting equal volumes $(20 \mathrm{ml})$ of organic-to-aqueous phases $(\mathrm{O} / \mathrm{A}=1)$ in a covered Erlenmeyer flask. The content was shook vigorously using a mechanical shaker with the help of magnetic stirrer to mix the two-phase mixture for a period of 15 minutes to reach equilibrium. After equilibration, the contents were allowed to stand for at least 10 minutes for separation of phases. The concentrations of $\mathrm{La}(\mathrm{III}), \mathrm{Nd}(\mathrm{III})$ and $\mathrm{Ce}(\mathrm{IV})$ in the aqueous phase before and after extraction were obtained by analysis with ICP-MS. All measurements were performed in duplicate under similar conditions with relative standard deviation less than $5 \%$. The concentrations of individual LREE ions in the organic phase were obtained by mass balance as shown in Equation 2.

$$
\left[C_{i}\right]_{\text {org }}=\left[C_{i}\right]_{F}-\left[C_{i}\right]_{a q}
$$

Where $\left[C_{i}\right]_{\text {org }},\left[C_{i}\right]_{\mathrm{F}}$ and $\left[C_{i}\right]_{a q}$ are the concentration of individual LRE ions ( $i=\mathrm{La}$ (III), $\mathrm{Nd}(\mathrm{III}), \mathrm{Ce}(\mathrm{IV}))$ in the organic phase, feed and aqueous phase respectively. The distribution ratio $(D)$ which is expressed as the ratio of the concentration of LREE present in the organic phase to that in the aqueous phase at equilibrium was determined using Equation 3:

$$
D=\left[C_{i}\right]_{\text {org }} /\left[C_{i}\right]_{a q}
$$

In addition to that, the extraction percent $(\% E)$ was obtained using $D$ with the following equation:

$$
\% E=(D \times 100) /\left(D+\left(V_{a q} / V_{\text {org }}\right)\right)
$$

where $V_{a q}$ and $V_{\text {org }}$ represent the volume of aqueous and organic phases, respectively. In this paper, $V_{a q} / V_{o r g}$ is equal to 1 .

Stripping The rare earth-loaded organic phase was stripped with various concentrations of acidic solutions $\left(\mathrm{H}_{2} \mathrm{SO}_{4}, \mathrm{HNO}_{3}\right.$ and $\mathrm{HCl}$ ) as the stripping agent. The experiments were carried out by shaking vigorously equal volume $(10 \mathrm{ml})$ of the organic phase with the solutions for a period of 15 minutes. The 
separated aqueous phase or strip liquor was analysed for the concentrations of metals content. The stripping percent $(\%$ Strip) was calculated with the following reaction:

$$
\left[C_{S} /\left(C_{o}-C\right) \times 100\right]
$$

where $C_{s}$ is the concentration of LREE in the strip liquor.

\section{RESULTS AND DISCUSSION}

\section{EXTRACTION}

Effect of Acid Concentration Effect of various acid (aqueous feed solutions) concentrations ranging from 0.1 to $0.5 \mathrm{M}$ of $\mathrm{HNO}_{3}$ and $\mathrm{H}_{2} \mathrm{SO}_{4}$ on the extraction of a mixture of LREE using $0.5 \mathrm{M}$ of D2EHPA was studied. Other parameters such as temperature and equilibrium time for this experiment were set at $298 \mathrm{~K}$ and 15 minutes respectively. The results obtained are shown in Figure 1.

Figure 1 shows that, in general, the extraction percentage of $\mathrm{La}$ and $\mathrm{Nd}$ decreases when the concentration of acid solutions increases. The extraction behaviour of $\mathrm{La}(\mathrm{III})$, $\mathrm{Nd}(\mathrm{III})$ and $\mathrm{Ce}(\mathrm{IV})$ with D2EHPA in kerosene resemblance that of D2EHPA in toluene for $\mathrm{HCl}$ (Peppard \& Wason 1961) and perchloric acid solutions (Piece \& Peck 1963). It is also shown that $\mathrm{Ce}$ was effectively extracted as the extraction percentage of $\mathrm{Ce}$ is found to be between 99.9 and $100 \%$ in all acid concentration regions. The extraction behaviour of $\mathrm{Ce}$ observed in this study is almost comparable to the extraction mechanism reported by Zhang et al. (2008).

The extraction trends of $\mathrm{La}, \mathrm{Nd}$ and $\mathrm{Ce}$ in both acidic medium were alike, where the extraction percentage

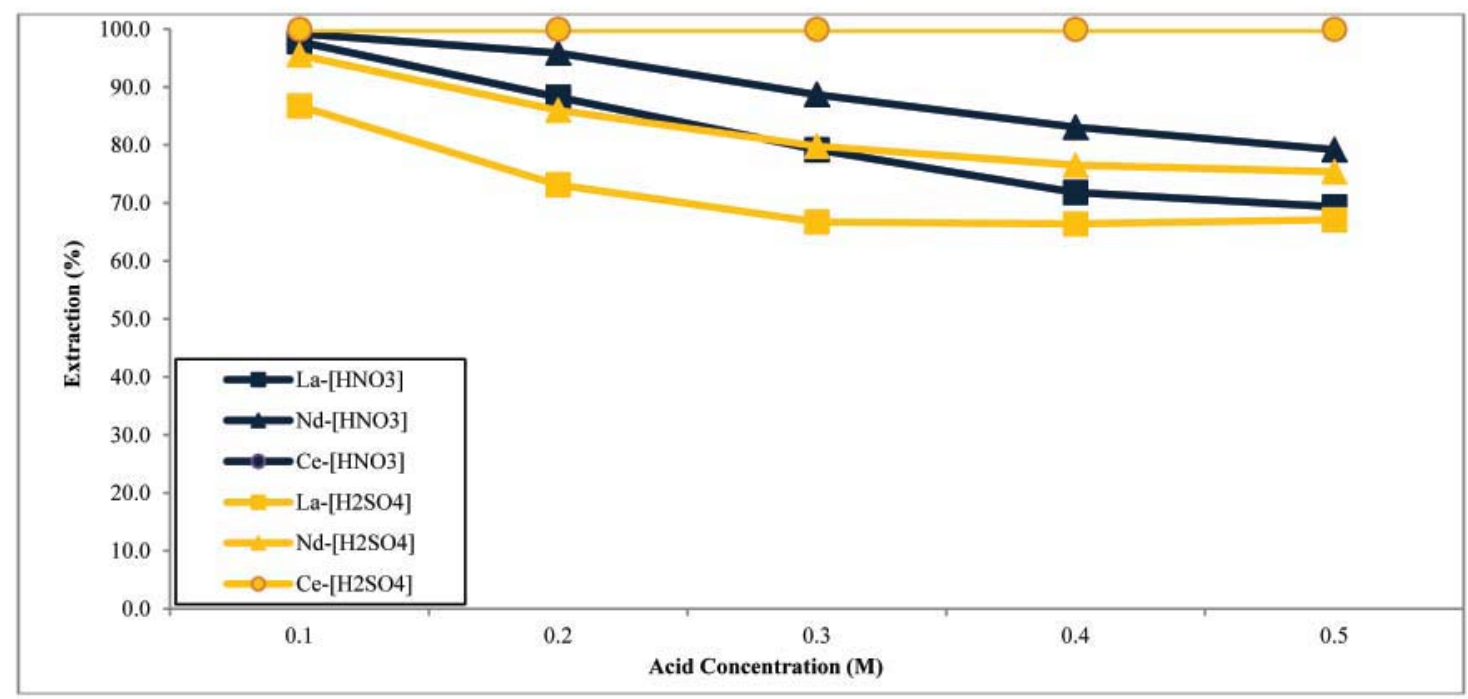

FIGURE 1. Effect of acid media concentration on percent extraction of LREE with 0.5M D2EHPA EFFECT OF D2EHPA CONCENTRATION

decreases as the acid concentration increases except for slightly disparity in the extraction percentage of each LREE. Between the two studied acidic solutions, the extraction of $\mathrm{La}, \mathrm{Nd}$ and Ce was considerably more effective in $\mathrm{HNO}_{3}$ than $\mathrm{H}_{2} \mathrm{SO}_{4}$. The highest extraction for $\mathrm{La}(99.4 \%), \mathrm{Nd}(99.7 \%)$ and $\mathrm{Ce}(100 \%)$ attained at $0.1 \mathrm{M} \mathrm{HNO}_{3}$.

The effect of varying D2EHPA concentration between 0.1 and $1.0 \mathrm{M}$ on the extraction of $\mathrm{La}, \mathrm{Nd}$ and $\mathrm{Ce}$ was studied. The concentrations of aqueous feed solutions in all experiments were fixed at $0.1 \mathrm{M}$. Other parameters, temperature and equilibrium time, were remained the same as the preceding experiment. The results are shown in Figure 2.

From the results, it is shown that the extraction percentage of all LREE increase when the concentrations of D2EHPA increase. At 0.1 M D2EHPA, all LREE were extracted in the range $71.7-100 \%$ in $\mathrm{HNO}_{3}$, and $66.1-99.9 \%$ in $\mathrm{H}_{2} \mathrm{SO}_{4}$. It is again found that the extraction of Ce was constant approaching $100 \%$ at very low concentration of D2EHPA. The result has confirmed that $\mathrm{Ce}(\mathrm{IV})$ is a stable compound and easily extracted even at low concentration of acidic medium and extractant (Zhang et al. 2008). The results show that the extraction percentage of $\mathrm{La}$ and $\mathrm{Nd}$ sharply increased after 0.1 M D2EHPA. At 0.5 M D2EHPA, the extraction percentage of $\mathrm{La}, \mathrm{Nd}$ and $\mathrm{Ce}$ was in the range $97.9-100 \%$ from $\mathrm{HNO}_{3}$ and $86.7-100 \%$ from $\mathrm{H}_{2} \mathrm{SO}_{4}$ respectively. The maximum extraction percentage reached was $99.4 \%$ for $\mathrm{La}, 99.7 \%$ for $\mathrm{Nd}$ and $100 \%$ for Ce at $1 \mathrm{M}$ D2EHPA using $0.1 \mathrm{M}$ of $\mathrm{HNO}_{3}$. The significant changes in the extraction percentage suggest that LREE in aqueous phase can be easily extracted using D2EHPA at high concentration. The concentration must be high enough for sufficient extraction capacity, but not as high as to compromise viscosity because high concentration would increase D2EHPA viscosity (Mansur et al. 2001). The extraction of the LREE from this study is in the order ability of $\mathrm{Ce}(\mathrm{IV})>\mathrm{Nd}(\mathrm{III})>\mathrm{La}(\mathrm{III})$. 


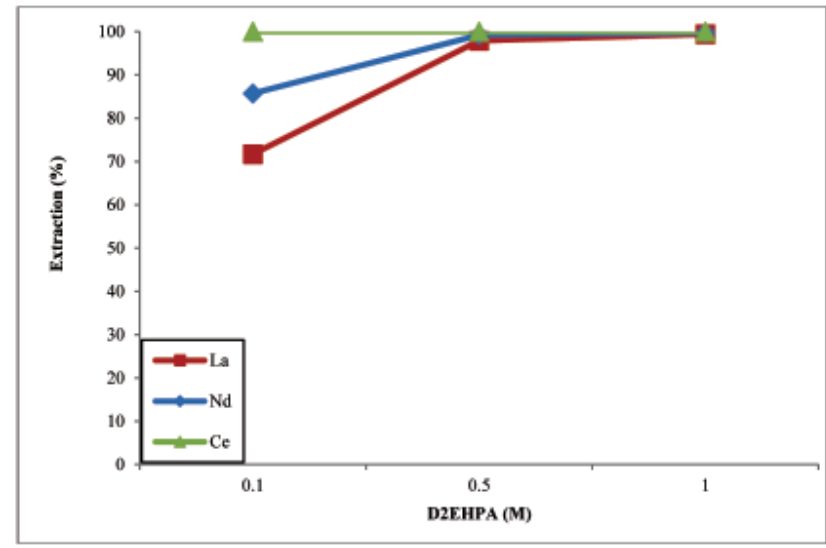

(a)

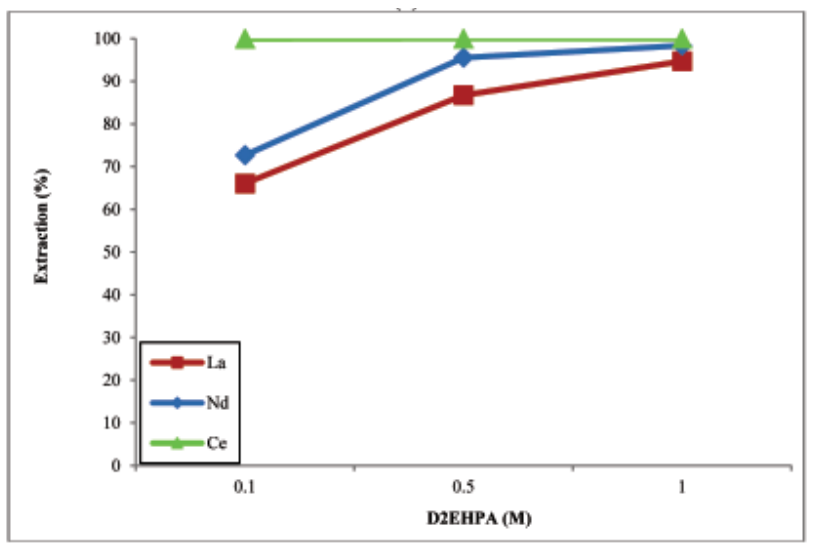

(b)

FIGURE 2. Effect of D2EHPA concentration on extraction of $\mathrm{La}, \mathrm{Nd}$ and $\mathrm{Ce}$ at $0.1 \mathrm{M}$ of (a) $\mathrm{HNO}_{3}$ and (b) $\mathrm{H}_{2} \mathrm{SO}_{4}$

It is of considerable interest to quantitatively compare the separation ability of the adjacent rare earth elements. The ratio of the two distribution factors of metal ion $A\left(D_{A}\right)$ and metal ion $B\left(D_{B}\right)$ is called separation factor $(\beta)$. However, the separation among mixed LREE in this study is unfeasible because all elements were nearly $100 \%$ extracted individually at $0.1 \mathrm{M}$ of the acidic solutions.

Effect of Equilibrium Time The extraction experiment of LREE with fixed concentration of D2EHPA (1M) and $\mathrm{HNO}_{3}$ $(0.1 \mathrm{M})$ was carried out at room temperature $(298 \mathrm{~K})$ with various shaking time range from 5 to $35 \mathrm{~min}$. The results were plotted as in Figure 3. It is seen that the extraction percentage of $\mathrm{La}$ and $\mathrm{Nd}$ was sharply increased after 5 minutes extraction. However, the curve for La and $\mathrm{Nd}$ flatten out from 10 minutes onwards with only $0.002 \%$ increase in $\mathrm{La}$ and $\mathrm{Nd}$ extraction percentage. The maximum extraction in operating conditions (equilibrium) obtained at about 15 minute. Similar equilibrium time effect was reported by Panda et al. (2012). Therefore, 15 minutes of shaking time for the aqueous-to-organic phase equal to 1 is sufficient for the extraction process to reach equilibrium and it was maintained in all experiments.

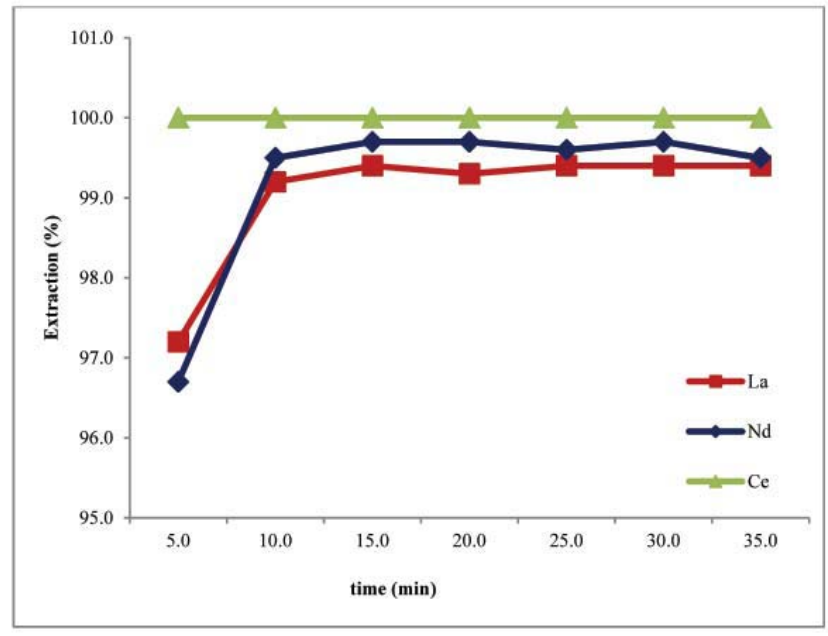

FIGURE 3. Effect of equilibrium time on the extraction of LREE $0.1 \mathrm{M} \mathrm{HNO}_{3}$ using 1.0 M D2EHPA

Effect of Temperature The effect of temperature on the LREE extraction in $0.1 \mathrm{M} \mathrm{HNO} 3$ with $1.0 \mathrm{M} \mathrm{D} 2 \mathrm{EHPA}$ was studied in the several temperature ranging from $278 \mathrm{~K}$ to $318 \mathrm{~K}$ at equilibrium time of $15 \mathrm{~min}$. It was found that the extraction percentage of each LREE does not change significantly in the temperature range studied. The experimental data obtained was plotted in Figure 4. It is obviously seen that the best extraction yield for each LREE was achieved at room temperature $(298 \mathrm{~K})$. The extraction for $\mathrm{La}$ and $\mathrm{Nd}$ were found to decline after reaching their highest values. This uncommon behaviour can be correlated with the strong complex formation between LREE ions and extractant that was stable in the organic phase. Thus, all the experiments were carried out at room temperature.

\section{STRIPPING OF LREE FROM LOADED D2EHPA}

Stripping is the reverse of the extraction, so it should be promoted by those factors that affect the extraction negatively

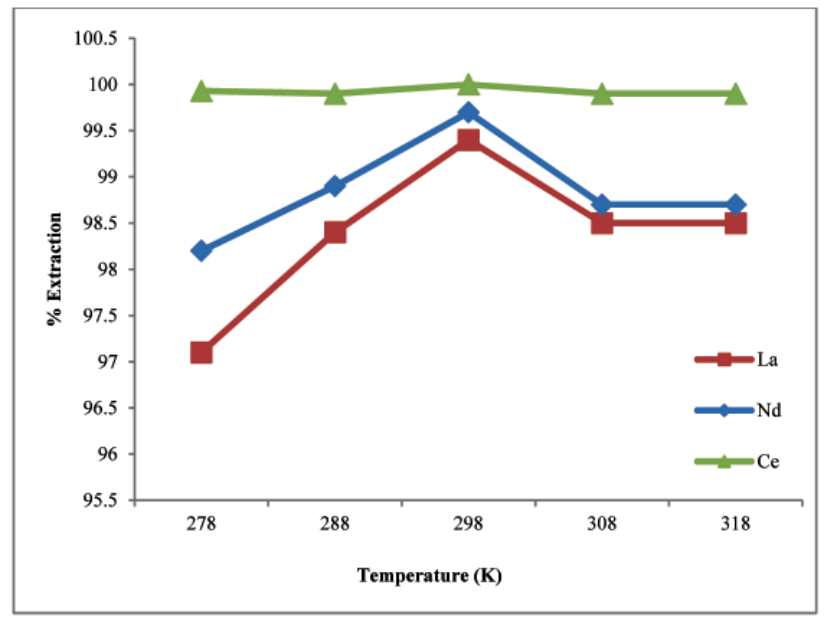

FIGURE 4. Effect of temperature on the extraction of LREE with 0.1 $\mathrm{M} \mathrm{HNO}_{3}$ using $1.0 \mathrm{M}$ D2EHPA 
such as acidic and salt media. Single stage stripping of loaded organic phase (1 M D2EHPA) was carried out with various concentrations $(1-6 \mathrm{M})$ of mineral acids $\left(\mathrm{HCl}, \mathrm{HNO}_{3}\right.$ and $\mathrm{H}_{2} \mathrm{SO}_{4}$ ), as stripping agents, at 1:1 phase ratio for 15 minutes. After vigorously shaking the content were left to stand for 10 minutes to settle and separate by gravity. The strip liquor was analysed for LREE concentrations. The experimental results to quantitatively compare the stripping behaviour are given in Table 1.

The data shows that the optimum recoveries from single stage stripping are about $67.7 \%$ of $\mathrm{La}$ and $59.5 \%$ of $\mathrm{Nd}$ in $4 \mathrm{M}$ of $\mathrm{H}_{2} \mathrm{SO}_{4}$. It is found that no successful of stripping of $\mathrm{Ce}(\mathrm{IV})$ in all conditions. This is probably due to the incomplete of ion pair complex dissociation (Kokare, B.N. et al. 2010). In practise, $4 \mathrm{M} \mathrm{H}_{2} \mathrm{SO}_{4}$ was opted as stripping agent for our further study. The experimental investigations with additional number of stripping stages and varying the phase ratios $(\mathrm{O} / \mathrm{A})$ to achieve a complete recovery of studied LREE will be carried out.

\section{CONCLUSION}

Under comparable conditions, nitric acid exhibited superior extraction for $\mathrm{La}(\mathrm{III}), \mathrm{Nd}(\mathrm{III})$ and Ce(IV) using D2EHPA. The extraction of $\mathrm{La}$ (III) and $\mathrm{Nd}$ (III) was improved by lowering the acidic medium concentration and raising D2EHPA concentration. On the contrary, Ce(IV) was completely extracted in all conditions. Entire set of experiments was performed at room temperature $(298 \mathrm{~K})$ with the contact time of 15 minutes in order to ensure the liquid equilibrium was reached. The selectivity order for extraction LREE from $0.1 \mathrm{M} \mathrm{HNO}_{3}$ with $1 \mathrm{M}$ D2EHPA in kerosene was $\mathrm{Ce}(\mathrm{IV})>\mathrm{Nd}$ (III) $>\mathrm{La}$ (III). Though the distribution coefficients of REE mostly increase with increasing atomic number, the nature of metal anion as well as the acidity of the aqueous phase could affect the separation factor. From the loaded organic phase, it was found that only $\mathrm{La}$ and $\mathrm{Nd}$ has shown tangible variations in stripped percentage using all stripping agents. During this single stage stripping experiments, about $67.7 \%$ of $\mathrm{La}$ and $59.5 \%$ of $\mathrm{Nd}$ was stripped with $4 \mathrm{M} \mathrm{H}_{2} \mathrm{SO}$ at a ratio $\mathrm{A} / \mathrm{O}$ of 1 . The recovery of $\mathrm{Ce}$ to the strip liquor was very low $(<1.5 \%)$. It is confirmed that D2EHPA can extract LREE at low concentration values, but hard to strip the loaded metals. Thereupon, further experimental stripping study is essential.

\section{REFERENCES}

Abdeltawab, A. A., Nii, S., Kawaizumi, F. \& Takahashi, K. 2002. Separation of La and Ce with PC-88A by countercurrent mixer-settler extraction column. Separation and Purification Technology 26(2): 265-272.

Antico, E., Masanaa, A., Hidalgo, M., Salvado, V., Iglesias, M. \& Valiente, M. 1996. Solvent extraction of yttrium from chloride media by di(2-ethylhexyl)phosphoric acid in kerosene. Speciation studies and gel formation. Analytica Chimica Acta 327(3): 267-276.

Basualto, C., Valenzuela, F., Molina, L., Munoz, J. P., Fuentes, E. \& Sapag, J. 2013. Study of the solvent extraction of the lighter lanthanide metal ions by means of organophosphorus extractants. Journal of Chilean Chemical Society 58(2): 1785-1789.

Brown, C. G. \& Sherrington, L. G. 1979. Solvent extraction used in industrial separation of rare earths. Journal of Chemical Technology and Biotechnology 29: 193-209.

Clark, A. M. 1984. 1984. Mineralogy of the rare earth elements - Rare Earth Element Geochemistry. P. Henderson. California: Elsevier Science.

Douglas, S. F. 2005. Solvent extraction in hydrometallurgy: the role of organophosphorus extractants. Journal of Organometallic Chemistry 690: 2426-2438.

Gupta, C. K. \& Krishnamurthy, N. 2005. Extractive Metallurgy of Rare-Earths. Boca Raton: CRC Press.

Huang, X., Li, J., Long, Z., Zang, Y., Xue, X. \& Zhu, Z. 2008. Synergistic extraction of rare earth by mixtures of 2-ethylhexyl phosphoric acid mono-2-ethylhexyl ester and di-(2-ethylhexyl) phosphoric acid from sulfuric acid medium. Journal of Rare Earths 26(3): 410-413.

Kokare, B. N., Mandhare, A. M. \& Anuse, M. A. 2010. Liquid-liquid extraction of cerium (IV) from salicylate media using n- $n$-octylaniline in xylene as extractant. $J$. Chil. Chem. Soc. 55(4): 430-435.

Li, H., Guo, F. L., Zhang, Z. \& Wang Li, D.Z. 2006. A new hydrometallurgical process for extracting rare earths from apatite using solvent extraction with $\mathrm{P}_{350}$. Journal of Alloys and Compound 995: 408-412.

TABLE 1. Percentage stripping of LREE from loaded organic phase (1.0 M D2EHPA) with various stripping agents

\begin{tabular}{|c|c|c|c|c|c|c|c|c|c|}
\hline \multirow{3}{*}{$\begin{array}{l}\text { Concentration } \\
\text { of stripping } \\
\text { agent, M }\end{array}$} & \multicolumn{9}{|c|}{ \% Stripping } \\
\hline & \multicolumn{3}{|c|}{$\mathrm{HCl}$} & \multicolumn{3}{|c|}{$\mathrm{HNO}_{3}$} & \multicolumn{3}{|c|}{$\mathrm{H}_{2} \mathrm{SO}_{4}$} \\
\hline & $\mathrm{La}$ & $\mathrm{Ce}$ & $\mathrm{Nd}$ & $\mathrm{La}$ & $\mathrm{Ce}$ & $\mathrm{Nd}$ & $\mathrm{La}$ & $\mathrm{Ce}$ & $\mathrm{Nd}$ \\
\hline 1 & 52.0 & 1.4 & 47.8 & 65.2 & 1.3 & 54.2 & 58.4 & 1.3 & 50.3 \\
\hline 2 & 57.7 & 1.4 & 55.5 & 65.5 & 1.3 & 55.4 & 67.6 & 1.3 & 57.7 \\
\hline 3 & 54.5 & 1.4 & 52.6 & 56.4 & 1.3 & 50.4 & 67.6 & 1.3 & 58.6 \\
\hline 4 & 51.3 & 1.3 & 49.8 & 47.3 & 1.1 & 45.4 & 67.7 & 1.3 & 59.5 \\
\hline 5 & 55.5 & 1.3 & 51.9 & 47.4 & 1.1 & 45.3 & 58.7 & 1.1 & 54.3 \\
\hline 6 & 59.7 & 1.3 & 53.9 & 47.2 & 1.1 & 45.2 & 49.7 & 1.0 & 49.1 \\
\hline
\end{tabular}


Mansur, M. B., Slater, M. J. \& Biscaia, E. C. 2001. Kinetic analysis of the reactive liquid-liquid test system $\mathrm{ZnSO} 4 /$ D2EHPA/n-heptan. Hydrometallurgy 63: 107-116.

Panda, N., Devi, N. \& Mishra, S. 2012. Solvent extraction of neodymium(III) from acidic nitrate medium using Cyanex 921 in kerosene. Journal of Rare Earths 30(8): 794-797.

Peppard, D. F., Driscoll, W. J., Siromen, S. J. \& Mason, G. W. 1957. Fractional extraction of the lanthanides as their di-alkyl-orthophosphates. Journal of Inorganic and Nuclear Chemistry 4: 334-343.

Peppard, D. F., Driscoll, W. J., Siromen, R. J. \& McCarty, S. 1957. No monotonic ordering of lanthanides in tributyl phosphate-nitric acid extraction system. Journal of Inorganic \& Nuclear Chemistry 4: 326-333.

Peppard, D. F., Farris, J. P., Gray, P. R. \& Mason, G. W. 1953. Study of the solvent extraction of the transition elements I order and degree of fractionation of the trivalent rare earth. Journal of Physical Chemistry 57: 94-301.

Peppard, D. F. \& Wason, G. W. 1961. Liquid-liquid extraction of trivalent rare earths using acidic phosphonates as extractants. Rare Earth Research, edited by Kleber E.V. New York: The Macmillan Company.

Khaironie Mohamed Takip* \& Masturah Markom Department of Chemical and Process Engineering Faculty of Engineering and Built Environment Universiti Kebangsaan Malaysia

43600 UKM Bangi, Selangor, Malaysia

Meor Yusoff Meor Sulaiman

Malaysia Nuclear Agency

43000 Bangi, Selangor, Malaysia

*Corresponding author; email: khaironie@gmail.com

Received date: $18^{\text {th }}$ December 2014

Accepted date: $7^{\text {th }}$ May 2015
Piece, T. B. \& Peck, P. F. 1963. The extraction of the lanthanide elements from perchloric acid by di-(2ethylhexyl) hydrogen phosphate. Analyst: 217-221.

Rabie, K. A. 2007. A group separation and purification of Sm, Eu and Gd from Egyptian beach monazite mineral using solvent extraction. Hydrometallurgy 85: 81-86.

Sato, T. 1989. Liquid-liquid extraction of rare-earth elements from aqueous acid solutions by acid organophosphorus compunds. Hydrometallurgy 22: 121-140.

Sherrington, L. 1983. Commercial process for rare earths and thorium- Handbook of Solvent Extraction. New York: Willey Interscience.

Thakur, N. V. 2000. Separation of rare-earths by solvent extraction. Mineral Processing and Extractive Metallurgy Review 21: 277-306.

Zhang, Z., Li, H., Guo, F., Meng, S. \& Li, D. 2008. Synergistic extraction and recovery of Cerium(IV) and Fluorin from sulphuric solutions with Cyanex 923 and di-2-ethylhexyl phosphoric acid. Separation and Purification Technology 63: 348-352. 